\title{
Endothelial cells and the IGF system
}

\author{
Leon A Bach ${ }^{1,2}$ \\ ${ }^{1}$ Department of Medicine (Alfred), Monash University, Prahran 3181, Australia \\ ${ }^{2}$ Department of Endocrinology and Diabetes, Alfred Hospital, Commercial Road, Melbourne 3004, Australia
}

Correspondence

should be addressed

to L A Bach

Email

leon.bach@monash.edu

\begin{abstract}
Endothelial cells line blood vessels and modulate vascular tone, thrombosis, inflammatory responses and new vessel formation. They are implicated in many disease processes including atherosclerosis and cancer. IGFs play a significant role in the physiology of endothelial cells by promoting migration, tube formation and production of the vasodilator nitric oxide. These actions are mediated by the IGF1 and IGF2/mannose 6-phosphate receptors and are modulated by a family of high-affinity IGF binding proteins. IGFs also increase the number and function of endothelial progenitor cells, which may contribute to protection from atherosclerosis. IGFs promote angiogenesis, and dysregulation of the IGF system may contribute to this process in cancer and eye diseases including retinopathy of prematurity and diabetic retinopathy. In some situations, IGF deficiency appears to contribute to endothelial dysfunction, whereas IGF may be deleterious in others. These differences may be due to tissue-specific endothelial cell phenotypes or IGFs having distinct roles in different phases of vascular disease. Further studies are therefore required to delineate the therapeutic potential of IGF system modulation in pathogenic processes.
\end{abstract}

\author{
Key Words \\ - insulin-like growth factor \\ - binding protein \\ - receptor \\ - endothelial cell \\ - angiogenesis
}

\section{Introduction}

Insulin-like growth factor 1 (IGF1) and IGF2 are essential for normal pre- and postnatal growth and development (Clemmons 2007, Pollak 2008). These peptide growth factors are synthesised in most tissues and circulate at nanomolar concentrations. They have endocrine, paracrine and autocrine actions. Most IGF actions are mediated by binding to the IGF1 receptor although the insulin receptor also has a role. The IGF2/mannose 6-phosphate receptor mediates some actions of IGF2 but predominantly acts as a clearance receptor. IGF actions are regulated by a family of six high-affinity IGF binding proteins (IGFBPs). IGFBP1, IGFBP2, IGFBP3, IGFBP4, IGFBP5 and IGFBP6 may inhibit or potentiate IGF actions and most also have IGF-independent actions.

Endothelial cells line blood vessels and act as barriers that control the transfer of biomolecules and cells from the circulation to tissues (Sumpio et al. 2002). They are metabolically active and regulate vascular tone, thrombosis, inflammatory responses and new vessel formation. Endothelial cell dysfunction is implicated in a range of diseases including atherosclerosis, inflammatory disorders and cancer. They are involved in IGF physiology and are targets of IGF actions, which is the subject of this review.

\section{The IGF system}

IGF1 and IGF2 share significant sequence homology with each other and with proinsulin (Clemmons 2007). In rodents, Igf2 expression decreases rapidly in most tissues after birth, whereas $I g f 1$ expression remains widespread, which has led to the view that IGF2 is a 'prenatal growth factor' and IGF1 is a 'postnatal growth factor'. However, IGF2 expression persists postnatally in humans and circulating IGF2 levels are higher than those of IGF1,

Published by Bioscientifica Ltd 
suggesting that it also has a postnatal role. IGF1 expression is regulated by growth hormone (GH), and IGF1 mediates many of the growth-promoting effects of the latter. By contrast, IGF2 expression is largely independent of GH. IGFs promote proliferation and survival of a wide range of cell types and increase differentiation of cells including myoblasts. IGFs also have insulin-like metabolic effects, decreasing plasma glucose after injection into humans and rodents and increasing glucose uptake into cells in vitro.

Most actions of IGF1 and IGF2 are mediated by the IGF1 receptor, a tyrosine kinase consisting of two heterodimers that has significant homology with the insulin receptor (Garrett et al. 1998). IGF binding to the IGF1 receptor results in activation of a number of signalling pathways including Ras/Raf/ERK and PI3 kinase/Akt. Some metabolic IGF actions are mediated by the insulin receptor, and some proliferative actions of IGF2 but not IGF1 are mediated by the insulin receptor isoform A (Frasca et al. 1999). Hybrid IGF/insulin receptors consisting of one heterodimer from each receptor have also been identified in many cells (Gatenby et al. 2013). These receptors preferentially bind IGF1 over insulin, but their physiological significance remains uncertain. The gene for the structurally distinct IGF2/mannose 6-phosphate receptor is imprinted and this receptor is largely involved with clearance of IGF2 but not IGF1; a limited number of studies have reported IGF2 actions that are mediated by this receptor (Brown et al. 2009).

IGF actions are finely regulated by a family of six highaffinity IGFBPs (Firth \& Baxter 2002, Bach et al. 2005, Baxter 2014). These proteins have three domains, with a high degree of homology within their N-and C-terminal domains, which both contain IGF-binding determinants. The linker domain between the $\mathrm{N}$ - and C-terminal domains is not conserved between IGFBPs and contains sites of post-translational modification (glycosylation and phosphorylation) that confer a degree of specificity to the actions of individual IGFBPs. The linker domains also contain sites for proteolysis by a number of specific proteases including matrix metalloproteases. IGFBP cleavage results in release of IGFs for binding to IGF receptors and may also modulate IGFBP interactions with the extracellular matrix. Almost all circulating IGFs are bound to IGFBPs either in binary complexes or in larger ternary complexes with IGFBP3 or IGFBP5 and an acidlabile subunit, thereby limiting their bioavailability. Ternary complexes, which incorporate $\sim 80 \%$ of circulating IGFs, cannot cross capillary walls, but free IGFs and those in binary complexes may leave the circulation and enter tissues (Fig. 1). IGFBPs localise to different tissue

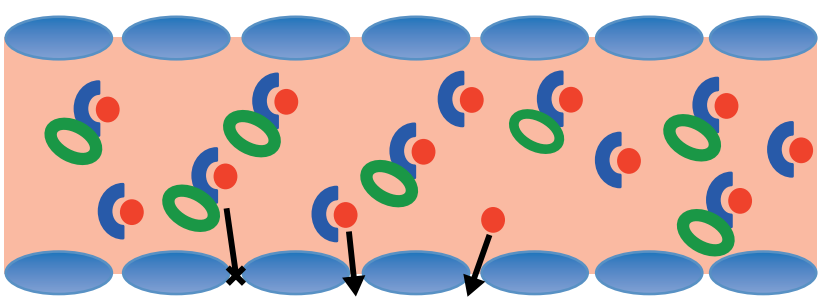

Figure 1

Role of the endothelium in transport of circulating IGFs. Most ( $80 \%)$ circulating IGFs (red) are bound in a high-molecular-weight ternary complex with IGFBP3 or IGFBP5 (blue) and an acid-labile subunit (green) that cannot leave the circulation. By contrast, IGFs in binary complexes with IGFBPs $(\sim 20 \%)$ and free IGFs $(\sim 1 \%)$ are able to traverse the endothelium into tissues.

compartments after leaving the circulation (Bar et al. 1990). In most situations, IGFBPs inhibit IGF actions, but they may also potentiate them under some conditions. Most IGFBPs also bind proteins other than IGFs, predominantly through their C-terminal and linker domains, and have actions that are independent of IGFs. IGFBPs are expressed by most tissues in a cell-type-specific manner.

The IGF system has been implicated in a range of diseases including atherosclerosis, diabetic complications and cancer. Endothelial cells are also implicated in these diseases and there is considerable evidence that components of the IGF system are expressed by and act upon these cells.

\section{Endothelial cells}

Endothelial cells form a monolayer that lines blood vessels (Sumpio et al. 2002). It has long been recognised that the endothelium functions as a barrier that regulates passage of biomolecules and cells such as leucocytes between the circulation and tissues. The endothelium is metabolically active and has an essential physiological role. Endothelial cells regulate vascular tone and blood flow via synthesis of mediators such as nitric oxide (NO), whereas thrombosis is regulated both by synthesis of key proteins and by interaction with platelets. Endothelial cells also regulate inflammatory responses by modulating interactions of inflammatory cells with blood vessel walls (Sumpio et al. 2002, Deanfield et al. 2007, Aird 2012). Endothelial cells play a key role in new vessel formation by angiogenesis and vasculogenesis. Endothelial cell responses to vascular endothelial growth factor (VEGF) via specific receptors such as VEGFR1 and VEGFR2 are an essential component of both of these processes. Many endothelial cell actions are mediated by synthesis of extracellular matrix proteins,

Published by Bioscientifica Ltd. 
anti-thrombotic and procoagulant factors, inflammatory mediators, proteases and vasomotor factors (Sumpio et al. 2002). In particular, endothelial cells synthesise and/or respond to a number of growth factors, including plateletderived growth factor (PDGF), epidermal growth factor, transforming growth factor beta (TGF $\beta$ ), and IGF1 and IGF2.

Endothelial cells show considerable heterogeneity depending on vessel type and size, and the tissue bed in which they reside (Aird 2012). For example, endothelial cells in large vessels are joined by tight junctions and form a continuous layer, whereas capillary endothelium has gaps of varying sizes in different tissues. There is also marked inter-individual variation in endothelial cell properties even if they derive from the same vessel. Endothelial cell heterogeneity is due to a combination of influences from the local microenvironment, which are changeable, and site-specific epigenetic effects, which are more stable. The phenotype of endothelial cells may therefore change as they are grown in vitro, hence caution is required when extrapolating from tissue culture studies to in vivo function.

Endothelial cells may be found in quiescent and activated states (Sumpio et al. 2002). Quiescent cells contribute to the maintenance of a non-thrombotic state by secreting vasodilators such as NO, which diffuses to adjacent vascular smooth muscle cells with subsequent relaxation, and prostacyclin. Cells are activated by a range of stimuli including injury and cytokines, resulting in generation of reactive oxygen species that results in a prothrombotic, proinflammatory phenotype (Deanfield et al. 2007).

Endothelial progenitor cells (EPCs), which are derived from bone marrow or vessel walls, promote vessel repair and prevent endothelial dysfunction (Conti et al. 2011, Higashi et al. 2012). They may differentiate to form a new endothelium or act as paracrine sources of cytokines and growth factors to enhance endothelial repair. EPC levels decrease with ageing and low levels correlate with adverse cardiovascular outcomes.

Endothelial dysfunction has a role in a wide range of diseases including atherosclerosis, allograft vasculopathy, hypertension, congestive heart failure, primary pulmonary hypertension, sepsis and inflammatory syndromes (Sumpio et al. 2002, Deanfield et al. 2007). Endothelial dysfunction may be a consequence of damage due to prolonged activation, resulting in a loss of their ability to compensate (Deanfield et al. 2007, Otsuka et al. 2012). As mentioned earlier, endothelial cells also play a major role in angiogenesis, which is essential for tumour growth and metastasis.

\section{IGF expression and regulation in endothelial cells}

IGF1 and IGF2 expression levels in endothelial cells are low (Tucci et al. 1998, Delafontaine et al. 2004). In bovine aortic and pulmonary endothelial cells, hypoxia decreased IGF1 but not IGF2 levels further (Tucci et al. 1998). In bovine aortic endothelial cells, TGFB1 decreased IGF1 mRNA whereas IGF1, insulin and angiotensin II had no effect (Dahlfors \& Arnqvist 2000). The IGF1 receptor is expressed by endothelial cells from large and small vessels (Chisalita \& Arnqvist 2004, Delafontaine et al. 2004), suggesting that these cells are responsive to IGFs, and IGF1 receptor levels are higher than those of insulin receptors (Chisalita \& Arnqvist 2004). Endothelial cells also express hybrid IGF1/insulin receptors, and their levels appear to be regulated by the abundance of each of the holoreceptors (Gatenby et al. 2013). The IGF2/mannose 6-phosphate receptor is also expressed in endothelial cells (Volpert et al. 1996).

Endothelial cells from large vessels and microvessels express IGFBP2, IGFBP3, IGFBP4, IGFBP5 and IGFBP6, with IGFBP2 and IGFBP3 predominating in microvessel cells, and IGFBP3 and IGFBP4 predominating in large vessel cells (Moser et al. 1992). By contrast, another study showed that IGFBP4 was the predominant IGFBP in two microvessel endothelial cell lines, and levels were increased by cAMP (Yang et al. 1993). In bovine aortic endothelial cells, VEGF decreased IGFBP3 and increased IGFBP5 mRNA and protein levels, whereas TGFB1 decreased IGFBP3 and IGFBP4 mRNAs, but only IGFBP3 protein (Dahlfors \& Arnqvist 2000). IGF1 increased IGFBP5 protein in these cells, but insulin and angiotensin II had no effect on IGFBP mRNA (Dahlfors \& Arnqvist 2000). Hypoxia increased low levels of IGFBP6 but had no effect on IGFBP4 levels in bovine aortic and pulmonary endothelial cells (Tucci et al. 1998). IGFBP3 was increased by hypoxia in pulmonary but not aortic cells, whereas IGFBP5 was decreased by hypoxia in aortic cells.

\section{IGF actions in endothelial cells}

Endothelial cells are metabolically active, and IGF1 increased amino acid and glucose uptake in microvessel endothelial cells (Boes et al. 1991). MAP kinase (MAPK), protein kinase $\mathrm{C}$ and PI3 kinase pathways were involved in IGF1-mediated glucose uptake in retinal endothelial cells (DeBosch et al. 2002). IGF1 stimulated migration of a number of microvessel and large vessel endothelial cell lines (Grant et al. 1987, Nakao-Hayashi et al. 1992), but had no effect on proliferation of bovine carotid

Published by Bioscientifica Ltd 
endothelial cells (Nakao-Hayashi et al. 1992). Endothelial cells form vessel-like tubes when grown on extracellular matrix and IGF1 enhanced this effect. IGF1 activated ERK and PI3 kinase pathways in bovine aortic endothelial cells, but only PI3 kinase activation was required for IGF1induced tube formation (Liu et al. 2001).

There is evidence that IGF1 acts as a vasodilator in vivo. GH-deficient patients with low IGF1 levels had impaired flow-mediated arterial dilation, which was endothelium dependent and NO mediated (Higashi et al. 2010). In untreated hypertensive adults, low plasma IGF1 levels were associated with reduced endothelial function as measured by acetylcholine (ACh)-stimulated forearm blood flow; by contrast, there was no correlation with endothelium-independent, sodium nitroprusside-induced vasodilation (Perticone et al. 2008). Mice with decreased circulating IGF1 levels due to liver-specific knockout of the Igf 1 gene had higher blood pressure than control mice, and this was attributed to impaired endothelium-dependent, NO-mediated vasorelaxation and enhanced expression of the vasoconstrictor endothelin (Tivesten et al. 2002). In another study, ACh-induced vasodilation of aortic rings from mice with liver-specific knockdown of $I g f 1$ was not significantly different from that of control mice; however, the response in Igf1-deficient mice was significantly impaired by oxidative stress induced by high glucose or oxidised LDL. The authors attributed this to an impaired antioxidant response that is dependent on the transcription factor Nrf2 (Nfe2l2) (Bailey-Downs et al. 2012). IGF1mediated vasorelaxation was impaired in spontaneously hypertensive rats, and a single session of aerobic exercise reversed this in an endothelium-dependent manner via increased PI3 kinase and NO synthase activity (Yang et al. 2010). In vitro, IGF1 stimulated NO production via PI3 kinase activation and endothelial NO synthase in human umbilical vein endothelial cells (Zeng \& Quon 1996).

IGF1 enhanced TNF-induced inflammatory responses in bovine aortic endothelial cells via Gab1, c-Jun and NFкB (Che et al. 2002). By contrast, IGF1 had no effect on TNFinduced inflammatory responses in human cardiac microvascular endothelial cells (Back et al. 2012). Another study showed that IGF1 inhibited proinflammatory human coronary artery endothelial cell activation by C-reactive protein through activating the PI3K/Akt pathway and suppressing the JNK and p38 pathways (Liu et al. 2014). The apparent contradiction between these results may reflect phenotypic differences between cells from different vascular beds.

Senescence is a cellular state of growth arrest and unresponsiveness to growth stimuli while remaining metabolically active. Endothelial cell senescence is associated with a proinflammatory phenotype and atherosclerosis. IGF1 receptor activation by IGF1 and IGF2 has been implicated in radiation-induced senescence of human pulmonary artery endothelial cells (Panganiban \& Day 2013). By contrast, IGF1 inhibited oxidative stressinduced senescence of human aortic endothelial cells (Higashi et al. 2013). IGFBP3 and IGFBP5 were upregulated in endothelial cells made senescent by serial culture in vitro (Shelton et al. 1999, Grillari et al. 2000). IGFBP3 overexpression increased aspects of the senescent phenotype in human umbilical vein endothelial cells, whereas IGFBP3 knockdown impaired this phenotype (Kim et al. 2007a). Some effects of IGFBP3 on senescence varied in cells from different donors (Muck et al. 2008). IGFBP5 induced senescence in human umbilical vein endothelial cells by a p53-dependent mechanism (Kim et al. 2007b). In these cells, IGFBP5 was identified as a potential candidate for senescence induced by radiation (Kim et al. 2014, Rombouts et al. 2014).

Similar to IGF1, IGF2 promoted migration and tube formation of human umbilical vascular endothelial cells, but had no effect on proliferation (Lee et al. 2000). Additionally, IGF2 increased p38 MAPK and p125 FAK phosphorylation. New vessel formation requires degradation of basement membranes by endothelial cells and this process involves proteases such as matrix metalloprotease 2 (MMP2); IGF2 promoted invasion of endothelial cells through extracellular matrix and increased MMP2 expression (Lee et al. 2000).

Depletion of the IGF1 receptor may contribute to endothelial cell apoptosis induced by advanced glycation end products (AGEs) (Pan et al. 2014), which increase with diabetes and ageing and are thought to be pathogenic. Microvesicles containing miRNA 223 were taken up by human umbilical vein endothelial cells resulting in decreased levels of the IGF1 receptor, and AGE-induced apoptosis was potentiated by this microRNA or by siRNA to the IGF1 receptor.

The IGF2/mannose 6-phosphate receptor was reported to mediate IGF2-induced migration of bovine adrenal capillary endothelial cells (Volpert et al. 1996). Similar to other endothelial cells, IGF2 increased migration and tube formation but had no effect on proliferation of human uterine endothelial cells (Herr et al. 2003). The IGF2/ mannose 6-phosphate receptor mediated IGF2-induced tube formation whereas the IGF1 and/or insulin receptor mediated tube formation induced by IGF1 or insulin. Protein kinase $C$ and $G_{i}$ proteins were implicated in the actions of IGF2. IGF2 also stimulated homing of EPCs,

Published by Bioscientifica Ltd. 
which may be important for vasculogenesis following hypoxia, via the IGF2/mannose 6-phosphate receptor, $\mathrm{G}_{\mathrm{i}}$ proteins and phospholipase $\mathrm{C}$ (Maeng et al. 2009). The IGF2/mannose 6-phosphate receptor binds many ligands other than IGF2, and interaction of mini-plasminogen with this receptor mediated TGFB-induced apoptosis of endothelial cells (Leksa et al. 2005).

\section{IGFs and atherosclerosis}

There is substantial interest in the role of the IGF system in cardiovascular disease. Many studies suggested that IGF1 may be proatherogenic, because it promotes vascular smooth muscle cell proliferation and migration, and its expression is increased in atherosclerotic plaques (Clemmons 2007). In particular, it is postulated that locally synthesised IGF1 from activated macrophages may directly stimulate atherogenic processes including smooth muscle cell proliferation.

However, IGF1 is also potentially protective both by enhancing endothelial cell function and promoting plaque stability through increased vascular smooth muscle cell survival (Conti et al. 2004, Ezzat et al. 2008). Many but not all studies have suggested that low-normal serum IGF1 levels correlate with an increased risk of adverse cardiovascular outcomes, including myocardial infarction and heart failure (Ezzat et al. 2008, Higashi et al. 2012). One potential explanation is that low IGF1 levels result in insulin resistance and accelerated atherosclerosis (Clemmons 2007). Obesity is associated with insulin resistance and atherosclerosis. Obesity induced by highfat feeding in mice resulted in impaired IGF1-mediated endothelial NO synthase activity and vasorelaxation (Imrie et al. 2009).

Another potential explanation is the effect of IGF1 on the number and function of EPCs, which decrease with age. These changes were reversed by increasing IGF1 levels with GH treatment in humans and mice (Thum et al. 2007a). IGF1 stimulated differentiation, migratory capacity and vascular network formation of EPCs from elderly individuals via the IGF1 receptor in vitro. IGF1 increased endothelial NO synthase expression, phosphorylation and activity via PI3 kinase/Akt in these cells. Additionally, GH-induced augmentation of IGF1 increased systemic NO bioavailability and the number of EPCs in healthy humans (Thum et al. 2007b). This is supported in part by a population study demonstrating that flow-mediated dilation, a measure of endothelial function, correlated with serum IGF1 levels in adult men but not women (Empen et al. 2010). IGF1 infusion increased the number of circulating EPCs and reduced inflammation and oxidative stress in the Apoe-null mouse model of atherosclerosis (Sukhanov et al. 2007). Additionally, IGF1 secreted by EPCs mediated myocardial repair after myocardial infarction in a porcine model (Hynes et al. 2013). In vivo, IGF1 infusion accelerated endothelial repair via an NO-dependent mechanism and increased EPC mobilisation after carotid artery injury in the rat (Cittadini et al. 2009).

A provocative hypothesis implicates hybrid IGF1/ insulin receptor formation in the development of insulin resistance and atherosclerosis. Hybrid receptors predominantly bind IGF1 rather than insulin, and, according to this hypothesis, formation of hybrids results in depletion of insulin receptors, thereby reducing insulin sensitivity (Gatenby et al. 2013). Several studies support this contention. At physiological concentrations, insulin activated the insulin receptor but not hybrid receptors in bovine aortic endothelial cells, whereas higher concentrations activated both (Li et al. 2005). Furthermore, endothelial cells have more IGF1 receptors than insulin receptors. Haploinsufficient $I g f 1 r^{+/-}$mice had decreased IGF1 receptors, enhanced insulin-mediated glucose disposal, restored insulin-mediated aortic vasorelaxation, and increased insulin-stimulated endothelial cell NO release (Abbas et al. 2011). Haploinsufficient $I g f 1 r^{+/-}$ mice also had fewer angiogenic progenitor cells than WT mice, but these cells had increased adhesion to fibronectin, increased IGF1 secretion and enhanced tube formation (Yuldasheva et al. 2014). Furthermore, infusion of these cells into WT mice increased endothelial repair without altering atherosclerotic lesion formation. Overexpression of IGF1 receptors on endothelial cells increased hybrid formation and reduced NO bioavailability (Imrie et al. 2012). However, perhaps surprisingly, endothelial regeneration was enhanced by IGF1 receptor overexpression after arterial denudation. The interplay between IGF1 and insulin, and the relative roles of their receptors in endothelial cells, clearly requires further study.

IGFBPs may also play a role in atherosclerosis via modulation of insulin sensitivity. IGFBP1 is acutely regulated by insulin, whereas IGFBP2 is also regulated by this hormone (Wheatcroft \& Kearney 2009). There is evidence that both of these IGFBPs may improve insulin sensitivity, especially in the context of overfeeding and obesity (Wheatcroft \& Kearney 2009, Hedbacker et al. 2010). Although most studies have not shown IGFBP1 expression in endothelial cells and direct regulation of IGFBP2 by insulin has also not been demonstrated in these cells, they would be exposed to circulating IGFBPs

Published by Bioscientifica Ltd 
that could act by modulating IGF actions or through IGF-independent mechanisms.

\section{IGFs and new vessel formation}

Vasculogenesis refers to new blood vessel formation from mesodermal EPCs during embryogenesis. By contrast, angiogenesis refers to the sprouting of new vessels from pre-existing vessels (Potente et al. 2011). Angiogenesis proceeds through a number of stages commencing with mobilisation of endothelial cells by proangiogenic signals. Endothelial cells then proliferate to extend the new vessel and a lumen is formed. Anastomoses between vessels result in loop formation, and vessels remodel and mature once blood flow commences.

Hypoxia is a major angiogenic stimulus, and hypoxiainducible factors (HIFs) regulate transcription of key angiogenic genes, including VEGF (Semenza 2012). HIF1 consists of HIF1A and ARNT subunits, and HIF1A, which is increased by hypoxia, is the main determinant of transcriptional activity. Both HIF1 and HIF2 play important roles in blood vessel development in vertebrates.

Angiogenesis is involved in a number of disease processes. Inadequate vessel formation contributes to ischaemic damage in diseases such as myocardial infarction and stroke. Therapeutic enhancers of angiogenesis are under development and have not reached clinical use. By contrast, increased angiogenesis is implicated in diseases including cancer and some forms of retinal damage. Indeed, it is integral to cancer progression at all stages, as it is required for oxygen and nutrient delivery to enlarging solid tumours beyond $1-2 \mathrm{~mm}^{3}$ (Potente et al. 2011), and it enhances metastasis by facilitating cancer cell entry into abnormal, tumour-induced vessels (Valastyan \& Weinberg 2011). Angiogenesis inhibitors are in clinical use for the treatment of a number of advanced cancers and eye diseases.

\section{Insulin-like growth factors}

Although VEGF pathways are central mediators of angiogenesis, IGFs also play a role (Carmeliet \& Jain 2000). As discussed in detail above, IGFs promote endothelial cell migration and tube formation in vitro. IGF1 and IGF2 stimulate HIF1A expression (Hoeben et al. 2004), and IGF1 induces VEGF synthesis (Warren et al. 1996, Stearns et al. 2005) via HIF1-dependent and independent pathways (Slomiany \& Rosenzweig 2006). IGF2 also plays a role in angiogenesis (Wang et al. 1998, Kim et al. 2012), at least in part by inducing VEGF synthesis (Hoeben et al. 2004). Although most IGF actions, including proangiogenic actions, are mediated by the IGF1 receptor, IGF2 may also promote angiogenesis via the insulin receptor (Bid et al. 2012). There has been considerable interest in IGF inhibition as treatment for a range of cancers, and some of the in vivo efficacy of these inhibitors is mediated by impaired angiogenesis (Dransfield et al. 2010).

IGFs are involved in early vascular development. Human embryonic and fetal lung explants expressed IGF1, IGF2, and IGF1 receptor as early as 4 weeks, and inhibiting the IGF1 receptor decreased the number of endothelial cells, due at least in part to apoptosis (Han et al. 2003). IGF2 increased vessel formation in a chick chorioallantoic membrane assay, which, together with its effects on human uterine endothelial cells, may be relevant to the vascular adaptation to pregnancy (Herr et al. 2003).

Angiogenesis is impaired in the diabetic heart, and a recent study has demonstrated that cardiomyocytes from rats with diabetes secreted exosomes containing miR320, which were subsequently taken up by endothelial cells (Wang et al. 2014). This microRNA decreased expression of a number of protein targets including IGF1, and inhibited endothelial cell migration and tube formation. However, the specific role of IGF1 as opposed to other protein targets was not studied.

\section{Insulin-like growth factor-binding proteins}

The roles of IGFBP2, IGFBP3, IGFBP4, IGFBP5 and IGFBP6 in angiogenesis have been studied. In general, IGFBP4, IGFBP5 and IGFBP6 inhibit angiogenesis and IGFBP2 enhances it, whereas there is evidence for both enhancement and inhibition by IGFBP3.

IGFBP2 Knockdown of IGFBP2 resulted in impaired vessel sprouting in zebrafish embryos (Wood et al. 2005). IGFBP2 increased angiogenesis via transcriptional regulation of VEGF (Azar et al. 2011). miR126 suppressed metastatic endothelial cell recruitment and angiogenesis by targeting a number of genes including IGFBP2 (Png et al. 2012). In this study, IGFBP2 increased endothelial cell chemotaxis and migration in vitro through an IGF1-dependent pathway.

IGFBP3 IGFBP3 inhibited vessel formation in prostate cancer xenografts, and a mutant of IGFBP3 that does not bind IGFs inhibited vessel formation in zebrafish embryos, indicating an IGF-independent effect (Liu et al. 2007). IGF1- and VEGF-induced proliferation and survival of human umbilical vein endothelial cells were both

Published by Bioscientifica Ltd 
inhibited by IGFBP3 (Franklin et al. 2003). IGFBP3 alone increased apoptosis, and IGFBP3 antagonised VEGF actions by an IGF-independent mechanism involving inhibition of PI3 kinase/Akt. IGFBP3 was also implicated in the antiangiogenic actions of a farnesyl transferase inhibitor that has anti-tumorigenic effects on head and neck squamous cell carcinomas (Oh et al. 2006). Furthermore, RUNX1, a transcription factor, promoted angiogenesis by suppressing $I g f b p 3$ expression (Iwatsuki et al. 2005).

In contrast to the above, comparison of doxorubicin and serum starvation-induced apoptosis of human umbilical vein endothelial cells suggests a more complex role for IGFBP3 (Granata et al. 2004). IGFBP3 enhanced the former but inhibited the latter, and these effects were mediated in an IGF1-dependent manner via sphingosine kinase and altered ceramide levels. IGFBP3 increased IGF1 secretion and phosphorylation of the IGF1 receptor, AKT and ERK according to this study. A subsequent study showed that IGFBP3 increased tube formation and angiogenesis-related gene expression including VEGF, MT1-MMP and MMP2, as well as increasing MMP2, and MMP9 activation (Granata et al. 2007). Incubation in high glucose increased death of primary human retinal microvascular endothelial cells and IGFBP3 inhibited this effect via the LRP1/TGFB receptor (Zhang et al. 2013a), which has been reported to mediate IGF-independent actions of this IGFBP (Huang et al. 2003). The anti-apoptotic effect of IGFBP3 was associated with increased AKT phosphorylation and Bcl-xL levels while cytochrome $c$, BAX and cleaved caspase 3 were decreased in these cells. Clearly, further studies are required to delineate the role of IGFBP3 in endothelial survival, function and angiogenesis in the face of these apparently disparate findings.

IGFBP4 Media conditioned by glioblastoma multiforme cells increased tube formation by human brain endothelial cells, and this effect was inhibited by IGFBP4. IGFBP4 also inhibited tube formation induced by IGF1, VEGF, FGF2 and PIGF, suggesting that its effects are IGF-independent (Moreno et al. 2006). IGFBP4 expression decreased upon exposure of human umbilical vein endothelial cells to denatured type IV collagen, which is found in angiogenic vessels (Contois et al. 2011). IGFBP4 inhibited angiogenesis induced by IGF1 and FGF2 but not VEGF in a chick chorioallantoic membrane assay. Adipose tissue expansion in response to high-fat feeding requires an expanded vasculostromal network. The angiogenic response was increased by insulin, which decreased IGFBP4 as well as altering expression of other genes (Gealekman et al. 2014).
Insulin increased IGF1 levels and both peptides stimulated sprout formation; IGFBP4 inhibited these effects.

IGFBP5 In human umbilical vein endothelial cells, IGFBP5 inhibited VEGF-induced proliferation, invasion, tube formation, and AKT and endothelial NO synthase phosphorylation (Rho et al. 2008). In the same study, IGFBP5 also inhibited vessel formation in a chick chorioallantoic membrane assay and angiogenesis in ovarian cancer xenografts.

IGFBP6 Overexpression of IGFBP6 inhibited angiogenesis in rhabdomyosarcoma xenografts and zebrafish embryos, as well as inhibiting tube formation in human umbilical vein endothelial cells through an IGF-independent mechanism (Zhang et al. 2012). Prolonged hypoxia increased IGFBP6 expression in human umbilical vein endothelial cells through a HIF1A-dependent mechanism. These findings suggest that IGFBP6 may be part of a negative feedback mechanism limiting hypoxia-induced angiogenesis (Messmer-Blust et al. 2009). Consistent with this, IGFBP6 was identified as a substrate for MMP2 in a proteomic screen of human umbilical vein endothelial cells for candidate angiogenic inhibitors that may be neutralised by this protease (Dean et al. 2007).

\section{Retinopathy}

Endothelial dysfunction and neovascularisation are implicated in a number of retinal diseases, including retinopathy of prematurity (ROP) and diabetic retinopathy.

\section{Retinopathy of prematurity}

ROP is a potentially sight-threatening disorder that arises in children born prematurely $(<31$ weeks, birth weight $<1250 \mathrm{~g}$ ) before the retinal vasculature has fully developed. It is thought to arise from inadequately vascularised, hypoxic retinal tissue generating signals that promote neovascularisation. These new vessels are abnormal and prone to bleeding and cause retinal detachment. ROP was more prevalent in the past when high concentrations of oxygen were used to treat premature babies in intensive care units.

In oxygen-induced retinopathy, a mouse model of ROP, IGF1 was required for maximal VEGF-dependent neovascularisation via the IGF1 receptor and MAPK activation (Smith et al. 1999). VEGF and IGF1 additively increased AKT phosphorylation in retinal endothelial cells, which promoted cell survival (Hellstrom et al. 2001). Igf1 knockout mice had impaired retinal vascular growth despite normal

Published by Bioscientifica Ltd. 
VEGF levels. ROP is associated with impaired vascular growth, and serum IGF1 levels were significantly lower in infants with ROP than in those without ROP. The authors postulated that the phase of neovascularisation occurs when IGF1 levels increased to reach a threshold after prolonged low levels. Knockout of IGF1 receptors in endothelial cells also decreased neovascularisation in oxygen-induced retinopathy (Kondo et al. 2003).

IGFBP3 has also been studied in oxygen-induced retinopathy (Chang et al. 2007, Lofqvist et al. 2007). IGFBP3 expression was regulated by hypoxia and it promoted differentiation of EPCs to endothelial cells. IGFBP3 also increased EPC migration, VEGFR1 and VEGFR 2 expression, and tube formation in vitro (Chang et al. 2007), as well as NO synthesis, which is required for homing into ischaemic tissue (Kielczewski et al. 2009). Igfbp3-deficient mice have more vessel loss after high oxygen exposure and less vessel regrowth after restoration of normoxia in a model of oxygen-induced retinopathy (Lofqvist et al. 2007). Exogenous IGFBP3 increased vessel regrowth in wild-type mice, possibly by promoting progenitor cell chemoattraction. Premature babies with ROP had lower IGFBP3 levels than those without ROP. The authors postulated that IGFBP3 might prevent retinal neovascularisation by inhibiting oxygen-induced vascular loss and promoting regrowth after vascular destruction. In support of this, plasmid-mediated IGFBP3 overexpression protected the retina from hyperoxia-induced vascular regression and subsequent neovascularisation (Chang et al. 2007).

\section{Diabetic retinopathy}

Diabetes mellitus is associated with a range of microvascular complications including retinopathy. Background retinopathy, which includes microaneurysm formation and vessel leakage resulting in protein exudates, small haemorrhages and infarcts, occurs in the vast majority of patients with an increasing duration of diabetes. A minority of patients then progress to sight-threatening proliferative retinopathy with neovascularisation, vitreous haemorrhage and retinal detachment. A significant proportion of patients also develop macular oedema. Diabetic retinopathy is the commonest cause of blindness in adults of working age in the western world.

The GH/IGF1 axis is implicated in diabetic retinopathy (Wilkinson-Berka et al. 2006). Early studies suggested that GH-deficient patients with diabetes were protected from retinopathy, and pituitary ablation, which decreases GH levels, was a treatment for severe retinopathy before the advent of laser photocoagulation. Overexpression of IGF1 in the retina resulted in changes similar to those of diabetic retinopathy (Ruberte et al. 2004). Subsequently, intraocular overexpression of IGF1 has been shown to result in breakdown of the blood-retinal barrier and increased retinal vascular permeability (Haurigot et al. 2009).

Expression of components of the IGF system was compared in human retinal endothelial cells from subjects with and without diabetes (Spoerri et al. 1998). Immunoreactive IGF1 receptor and IGFBP1, IGFBP3 and IGFBP5 were increased with diabetes, whereas IGF1 and IGFBP4 were decreased. IGFBP1, IGFBP2 and IGFBP5 mRNA levels were increased with diabetes, whereas IGF1 mRNA decreased and mRNA levels of IGFBP3, IGFBP4 and IGF1R were unchanged. These findings suggest that diabetes alters IGF system components at both transcriptional and post-transcriptional levels.

Another study demonstrated that human retinal endothelial cells secrete IGFBP2, IGFBP3, IGFBP4 and IGFBP5 (Giannini et al. 2001). GH, VEGF, FGF2 and PDGF had no effect on IGFBP levels, whereas IGF1 decreased IGFBP4 and increased IGFBP5 levels. IGF1 increased thymidine incorporation in these cells, while IGFBP5 alone also had a minor effect. High glucose (22 mM) incubation decreased basal thymidine incorporation after 14-21 days and also decreased IGFBP2, IGFBP3 and IGFBP5 protein but not mRNA levels. These results differ from the above comparison of retinal endothelial cells from patients with and without diabetes (Spoerri et al. 1998), reflecting the need for caution in interpreting in vitro results.

IGFBP3 reduced monocyte-endothelial cell adhesion in an IGF-independent manner by decreasing ICAM1 levels in human retinal endothelial cells cultured in a high glucose medium (Zhang et al. 2013b). It was postulated that this anti-inflammatory effect may be protective in the setting of diabetic nephropathy, which is supported by a study showing that TNFA, which is proinflammatory, reduced IGFBP3 expression in retinal endothelial cells via activation of $\mathrm{p} 38 \alpha \mathrm{MAPK}$ and casein kinase 2 under high glucose conditions (Zhang et al. 2014). Furthermore, IGFBP3 inhibited whereas TNFA increased retinal endothelial cell apoptosis (Zhang et al. 2013c).

There appears to be a paradox whereby IGF1 deficiency is thought to be deleterious in ROP, whereas IGF1 excess is implicated in diabetic retinopathy. However, this may be an oversimplistic interpretation, as these disease processes are dynamic and the role of the IGF system may differ depending on the stage of the disease. Thus, increasing

Published by Bioscientifica Ltd. 


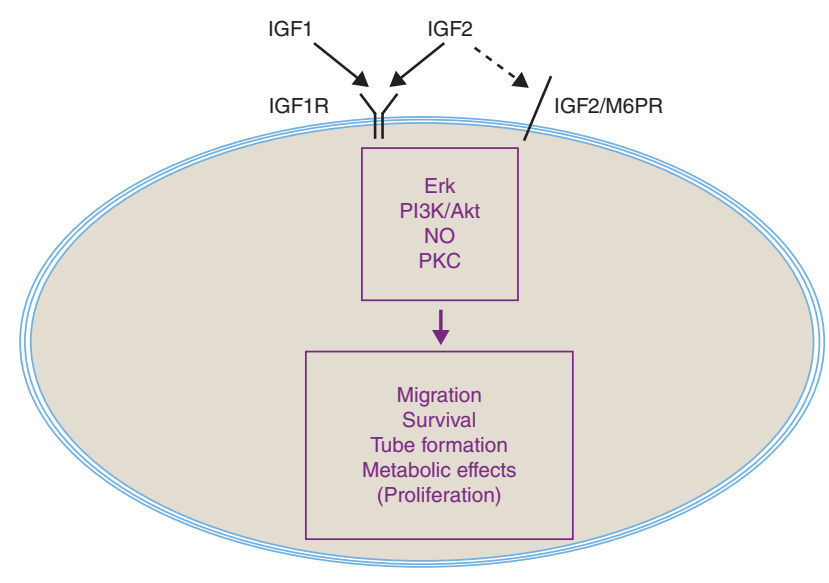

Figure 2

Actions of IGFs on endothelial cells. Most actions of IGF1 and IGF2 are mediated by the IGF1 receptor (IGF1R), although there is evidence that some IGF2 actions are mediated by IGF2/mannose 6-phosphate receptor (IGF2/M6PR). A number of signalling pathways, including Erk, PI3K/Akt, NO and PKC are activated by IGFs resulting in endothelial cell migration, survival, nutrient uptake and tube formation. In some studies, IGFs also stimulate proliferation.

IGF1 may promote normal retinal vascular growth and prevent tissue hypoxia in the early phases of ROP, whereas IGF inhibition may limit neovascularisation later in the course of ROP and in diabetic retinopathy.

\section{Conclusions}

Endothelial cells play an important role in maintaining homoeostasis, and they are constantly exposed to circulating IGFs. They express IGF and insulin receptors and are responsive to IGFs at concentrations sufficient to activate these receptors (Fig. 2). This raises the question as to how IGF responses are limited. One mechanism is binding of the vast majority of circulating IGFs to IGFBPs in binary and ternary complexes, within which they are not accessible to receptors. Another question is how circulating IGFs traverse the endothelium to access tissues. Capillary endothelium contains gaps between cells, and there is evidence that IGFs utilise this paracellular pathway (Bastian et al. 1997). Insulin traverses the endothelium by a transcytotic pathway that involves insulin and IGF1 receptors (Wang et al. 2006), so it remains possible that IGFs also utilise this pathway. Binary complexes containing IGFs and IGFBPs can traverse the endothelium and the latter have a role in regulating this process (Boes et al. 2003).

The evidence suggests that the effects of IGFs on endothelial cells can be both protective and pathogenic in a range of diseases. For example, ROP is biphasic, and IGF deficiency appears to have a role in the first ischaemic phase, whereas IGFs may contribute to the subsequent phase of neovascularisation. At a more general level, angiogenesis, to which IGFs contribute, is important for tissue repair in situations such as myocardial ischaemia but deleterious in malignancy. The interplay between insulin and IGFs and their receptors, including hybrid receptors, also appears to contribute to insulin sensitivity and endothelial responses that may contribute to atherosclerosis. There are means of enhancing IGF action such as recombinant GH or IGF1 itself, and means of inhibition such as IGF1 receptor antibodies and small molecule inhibitors. It is important to develop approaches to target these potential treatments to specific sites, but it is equally important for further studies to delineate potential positive and negative effects and define possible switches between them.

\section{Declaration of interest}

The author declares that there is no conflict of interest that could be perceived as prejudicing the impartiality of this review.

\section{Funding}

This research did not receive any specific grant from any funding agency in the public, commercial or not-for-profit sector.

\section{References}

Abbas A, Imrie H, Viswambharan H, Sukumar P, Rajwani A, Cubbon RM, Gage M, Smith J, Galloway S, Yuldeshava N et al. 2011 The insulin-like growth factor-1 receptor Is a negative regulator of nitric oxide bioavailability and insulin sensitivity in the endothelium. Diabetes 60 2169-2178. (doi:10.2337/db11-0197)

Aird WC 2012 Endothelial cell heterogeneity. Cold Spring Harbor Perspectives in Medicine 2 a006429. (doi:10.1101/cshperspect.a006429)

Azar WJ, Azar SHX, Higgins S, Hu JF, Hoffman AR, Newgreen DF, Werther GA \& Russo VC 2011 IGFBP-2 enhances vegf gene promoter activity and consequent promotion of angiogenesis by neuroblastoma cells. Endocrinology 152 3332-3342. (doi:10.1210/en.2011-1121)

Bach LA, Headey SJ \& Norton RS 2005 IGF-binding proteins - the pieces are failing into place. Trends in Endocrinology and Metabolism 16 228-234. (doi:10.1016/j.tem.2005.05.005)

Back K, Islam R, Johansson GS, Chisalita SI \& Arnqvist HJ 2012 Insulin and IGF1 receptors in human cardiac microvascular endothelial cells: metabolic, mitogenic and anti-inflammatory effects. Journal of Endocrinology 215 89-96. (doi:10.1530/JOE-12-0261)

Bailey-Downs LC, Mitschelen M, Sosnowska D, Toth P, Pinto JT, Ballabh P, Valcarcel-Ares MN, Farley J, Koller A, Henthorn JC et al. 2012 Liver-specific knockdown of IGF-1 decreases vascular oxidative stress resistance by impairing the Nrf2-dependent antioxidant response: a novel model of vascular aging. Journals of Gerontology Series A: Biological Sciences and Medical Sciences 67 313-329. (doi:10.1093/gerona/glr164)

Bar RS, Clemmons DR, Boes M, Busby WH, Booth BA, Dake BL \& Sandra A 1990 Transcapillary permeability and subendothelial distribution of

Published by Bioscientifica Ltd. 
endothelial and amniotic fluid insulin-like growth factor binding proteins in the rat heart. Endocrinology 127 1078-1086. (doi:10.1210/ endo-127-3-1078)

Bastian SEP, Walton PE \& Belford DA 1997 Paracellular transport of insulinlike growth factor-I (IGF-I) across human umbilical vein endothelial cell monolayers. Journal of Cellular Physiology 170 290-298. (doi:10. 1002/(SICI)1097-4652(199703)170:3 < 290::AID-JCP10>3.0.CO;2-J)

Baxter RC 2014 IGF binding proteins in cancer: mechanistic and clinical insights. Nature Reviews. Cancer 14 329-341. (doi:10.1038/nrc3720)

Bid HK, Zhan J, Phelps DA, Kurmasheva RT \& Houghton PJ 2012 Potent inhibition of angiogenesis by the IGF-1 receptor-targeting antibody SCH717454 Is reversed by IGF-2. Molecular Cancer Therapeutics 11 649-659. (doi:10.1158/1535-7163.MCT-11-0575)

Boes M, Dake BL \& Bar RS 1991 Interactions of cultured endothelial cells with TGF- $\beta$, bFGF, PDGF and IGF-I. Life Sciences 48 811-821. (doi:10. 1016/0024-3205(91)90097-U)

Boes M, Dake BL, Booth BA, Sandra A, Bateman M, Knudtson KL \& Bar RS 2003 IGF-I and IGFBP-3 transport in the rat heart. American Journal of Physiology. Endocrinology and Metabolism 284 E237-E239. (doi:10.1152/ ajpendo.00336.2002)

Brown J, Jones EY \& Forbes BE 2009 Keeping IGF-II under control: lessons from the IGF-II-IGF2R crystal structure. Trends in Biochemical Sciences 34 612-619. (doi:10.1016/j.tibs.2009.07.003)

Carmeliet P \& Jain RK 2000 Angiogenesis in cancer and other diseases. Nature 407 249-257. (doi:10.1038/35025220)

Chang KH, Chan-Ling T, McFarland EL, Afzal A, Pan H, Baxter LC, Shaw LC, Caballero S, Sengupta N, Calzi SL et al. 2007 IGF binding protein-3 regulates hematopoietic stem cell and endothelial precursor cell function during vascular development. PNAS 104 10595-10600. (doi:10.1073/pnas.0702072104)

Che WY, Lerner-Marmarosh N, Huang QH, Osawa M, Ohta S, Yoshizumi M, Glassman M, Lee JD, Yan C, Berk BC et al. 2002 Insulin-like growth factor-1 enhances inflammatory responses in endothelial cells - role of Gab1 and MEKK3 in TNF- $\alpha$-induced c-Jun and NF- $\kappa$ B activation and adhesion molecule expression. Circulation Research 90 1222-1230. (doi:10.1161/01.RES.0000021127.83364.7D)

Chisalita SI \& Arnqvist HJ 2004 Insulin-like growth factor I receptors are more abundant than insulin receptors in human micro- and macrovascular endothelial cells. American Journal of Physiology. Endocrinology and Metabolism 286 E896-E901. (doi:10.1152/ajpendo.00327.2003)

Cittadini A, Monti MG, Castiello MC, D’Arco E, Galasso G, Sorriento D, Saldamarco L, De Paulis A, Napoli R, Iaccarino G et al. 2009 Insulin-like growth factor-1 protects from vascular stenosis and accelerates re-endothelialization in a rat model of carotid artery injury. Journal of Thrombosis and Haemostasis 7 1920-1928. (doi:10.1111/j.1538-7836.2009.03607.x)

Clemmons DR 2007 Modifying IGF1 activity: an approach to treat endocrine disorders, atherosclerosis and cancer. Nature Reviews. Drug Discovery 6 821-833. (doi:10.1038/nrd2359)

Conti E, Carrozza C, Capoluongo E, Volpe M, Crea F, Zuppi C \& Andreotti F 2004 Insulin-like growth factor-1 as a vascular protective factor. Circulation 110 2260-2265. (doi:10.1161/01.CIR.0000144309.87183.FB)

Conti E, Musumeci MB, De Giusti M, Dito E, Mastromarino V, Autore C \& Volpe M 2011 IGF-1 and atherothrombosis: relevance to pathophysiology and therapy. Clinical Science 120 377-402. (doi:10.1042/ CS20100400)

Contois LW, Nugent DP, Caron JM, Cretu A, Tweedie E, Akalu A, Liebes L, Friesel R, Rosen C, Vary C et al. 2011 Insulin-like growth factor binding protein-4 (IGFBP-4) differentially inhibits growth factor-induced angiogenesis. Journal of Biological Chemistry 287 1779-1789. (doi:10.1074/jbc.M111.267732)

Dahlfors G \& Arnqvist HJ 2000 Vascular endothelial growth factor and transforming growth factor- $\beta 1$ regulate the expression of insulin-like growth factor-binding protein-3, -4 , and -5 in large vessel endothelial cells. Endocrinology 141 2062-2067. (doi:10.1210/endo.141.6.7481)

Dean RA, Butler GS, Hamma-Kourbali Y, Delbe J, Brigstock DR, Courty J \& Overall CM 2007 Identification of candidate angiogenic inhibitors processed by matrix metalloproteinase 2 (MMP-2) in cell-based proteomic screens: disruption of vascular endothelial growth factor (VEGF)/heparin affin regulatory peptide (pleiotrophin) and VEGF/ connective tissue growth factor angiogenic inhibitory complexes by MMP-2 proteolysis. Molecular and Cellular Biology 27 8454-8465. (doi:10.1128/MCB.00821-07)

Deanfield JE, Halcox JP \& Rabelink TJ 2007 Endothelial function and dysfunction: testing and clinical relevance. Circulation 115 1285-1295. (doi:10.1161/CIRCULATIONAHA.106.652859)

DeBosch BJ, Deo BK \& Kumagai AK 2002 Insulin-like growth factor-1 effects on bovine retinal endothelial cell glucose transport: role of MAP kinase. Journal of Neurochemistry 81 728-734. (doi:10.1046/j.1471-4159.2002. 00848.x)

Delafontaine P, Song YH \& Li YX 2004 Expression, regulation, and function of IGF-1, IGF-1R, and IGF-1 binding proteins in blood vessels. Arteriosclerosis, Thrombosis, and Vascular Biology 24 435-444. (doi:10.1161/01.ATV.0000105902.89459.09)

Dransfield DT, Cohen EH, Chang Q, Sparrow LG, Bentley JD, Dolezal O, Xiao X, Peat TS, Newman J, Pilling PA et al. 2010 A human monoclonal antibody against insulin-like growth factor-II blocks the growth of human hepatocellular carcinoma cell lines in vitro and in vivo. Molecular Cancer Therapeutics 9 1809-1819. (doi:10.1158/1535-7163. MCT-09-1134)

Empen K, Lorbeer R, Volzke H, Robinson DM, Friedrich N, Krebs A, Nauck M, Reffelmann T, Ewert R, Felix SB et al. 2010 Association of serum IGF1 with endothelial function: results from the populationbased study of health in Pomerania. European Journal Endocrinology 163 617-623. (doi:10.1530/EJE-10-0563)

Ezzat VA, Duncan ER, Wheatcroft SB \& Kearney MT 2008 The role of IGF-I and its binding proteins in the development of type 2 diabetes and cardiovascular disease. Diabetes, Obesity \& Metabolism 10 198-211. (doi:10.1111/j.1463-1326.2007.00709.x)

Firth SM \& Baxter RC 2002 Cellular actions of the insulin-like growth factor binding proteins. Endocrine Reviews 23 824-854. (doi:10.1210/ er.2001-0033)

Franklin SL, Ferry RJ \& Cohen P 2003 Rapid insulin-like growth factor (IGF)-independent effects of IGF binding protein-3 on endothelial cell survival. Journal of Clinical Endocrinology and Metabolism 88 900-907. (doi:10.1210/jc.2002-020472)

Frasca F, Pandini C, Scalia P, Sciacca L, Mineo R, Costantino A, Goldfine ID, Belfiore A \& Vigneri R 1999 Insulin receptor isoform A, a newly recognized, high-affinity insulin-like growth factor II receptor in fetal and cancer cells. Molecular and Cellular Biology 19 3278-3288.

Garrett TPJ, McKern NM, Lou MZ, Frenkel MJ, Bentley JD, Lovrecz GO, Elleman TC, Cosgrove LJ \& Ward CW 1998 Crystal structure of the first three domains of the type-1 insulin-like growth factor receptor. Nature 394 395-399. (doi:10.1038/28668)

Gatenby VK, Imrie H \& Kearney M 2013 The IGF-1 receptor and regulation of nitric oxide bioavailability and insulin signalling in the endothelium. Pflugers Archiv 465 1065-1074. (doi:10.1007/ s00424-013-1218-z)

Gealekman O, Gurav K, Chouinard M, Straubhaar J, Thompson M, Malkani S, Hartigan C \& Corvera S 2014 Control of adipose tissue expandability in response to high fat diet by the insulin-like growth factor-binding protein-4. Journal of Biological Chemistry 289 18327-18338. (doi:10.1074/jbc.M113.545798)

Giannini S, Cresci B, Pala L, Ciucci A, Franchini A, Manuelli C, Fujita-Yamaguchi Y, Cappugi P, Zonefrati R \& Rotella CM 2001 IGFBPs modulate IGF-I- and high glucose-controlled growth of human retinal endothelial cells. Journal of Endocrinology 171 273-284. (doi:10.1677/ joe.0.1710273)

Granata R, Trovato L, Garbarino G, Taliano M, Ponti R, Sala G, Ghidoni R \& Ghigo E 2004 Dual effects of IGFBP-3 on endothelial cell apoptosis and survival: involvement of the sphingolipid signaling pathways. FASEB Journal 18 1456-1458. (doi:10.1096/fj.04-1618fje) 
Granata R, Trovato L, Lupia E, Sala G, Settanni F, Camussi G, Ghidoni R \& Ghigo E 2007 Insulin-like growth factor binding protein-3 induces angiogenesis through IGF-I- and SphK1-dependent mechanisms. FASEB Journal 5 835-845. (doi:10.1111/j.1538-7836.2007.02431.x)

Grant M, Jerdan J \& Merimee TJ 1987 Insulin-like growth factor-I modulates endothelial cell chemotaxis. Journal of Clinical Endocrinology and Metabolism 65 370-371. (doi:10.1210/jcem-65-2-370)

Grillari J, Hohenwarter O, Grabherr RM \& Katinger H 2000 Subtractive hybridization of mRNA from early passage and senescent endothelial cells. Experimental Gerontology 35 187-197. (doi:10.1016/ S0531-5565(00)00080-2)

Han RNN, Post M, Tanswell AK \& Lye SJ 2003 Insulin-like growth factor-I receptor-mediated vasculogenesis/angiogenesis in human lung development. American Journal of Respiratory Cell and Molecular Biology 28 159-169. (doi:10.1165/rcmb.4764)

Haurigot V, Villacampa P, Ribera A, Llombart C, Bosch A, Nacher V, Ramos D, Ayuso E, Segovia JC, Bueren JA et al. 2009 Increased intraocular insulin-like growth factor-I triggers blood-retinal barrier breakdown. Journal of Biological Chemistry 284 22961-22969. (doi:10.1074/jbc.M109.014787)

Hedbacker K, Birsoy KV, Wysocki RW, Asilmaz E, Ahima RS, Farooqi IS \& Friedman JM 2010 Antidiabetic effects of IGFBP2, a leptin-regulated gene. Cell Metabolism 11 11-22. (doi:10.1016/j.cmet.2009.11.007)

Hellstrom A, Perruzzi C, Ju M, Engstrom E, Hard AL, Liu JL, AlbertssonWikland K, Carlsson B, Niklasson A, Sjodell L et al. 2001 Low IGF-I suppresses VEGF-survival signaling in retinal endothelial cells: direct correlation with clinical retinopathy of prematurity. PNAS 98 5804-5808. (doi:10.1073/pnas.101113998)

Herr F, Liang OD, Herrero J, Lang U, Preissner KT, Han VKM \& Zygmunt M 2003 Possible angiogenic roles of insulin-like growth factor II and its receptors in uterine vascular adaptation to pregnancy. Journal of Clinical Endocrinology and Metabolism 88 4811-4817. (doi:10.1210/ jc.2003-030243)

Higashi Y, Sukhanov S, Anwar A, Shai SY \& Delafontaine P 2010 IGF-1, oxidative stress and atheroprotection. Trends in Endocrinology and Metabolism 21 245-254. (doi:10.1016/j.tem.2009.12.005)

Higashi Y, Sukhanov S, Anwar A, Shai SY \& Delafontaine P 2012 Aging, atherosclerosis, and IGF-1. Journals of Gerontology Series A: Biological Sciences and Medical Sciences 67 626-639. (doi:10.1093/gerona/gls102)

Higashi Y, Pandey A, Goodwin B \& Delafontaine P 2013 Insulin-like growth factor-1 regulates glutathione peroxidase expression and activity in vascular endothelial cells: implications for atheroprotective actions of insulin-like growth factor-1. Biochimica et Biophysica Acta 1832 391-399. (doi:10.1016/j.bbadis.2012.12.005)

Hoeben A, Landuyt B, Highley MS, Wildiers H, Van Oosterom AT \& De Bruijn EA 2004 Vascular endothelial growth factor and angiogenesis. Pharmacological Reviews 56 549-580. (doi:10.1124/pr.56.4.3)

Huang SS, Ling TY, Tseng WF, Huang YH, Tang FM, Leal SM \& Huang JS 2003 Cellular growth inhibition by IGFBP-3 and TGF- $\beta(1)$ requires LRP-1. FASEB Journal 17 2068-2081. (doi:10.1096/fj.03-0256com)

Hynes B, Kumar AH, O'Sullivan J, Klein Buneker C, Leblond AL, Weiss S, Schmeckpeper J, Martin K \& Caplice NM 2013 Potent endothelial progenitor cell-conditioned media-related anti-apoptotic, cardiotrophic, and pro-angiogenic effects post-myocardial infarction are mediated by insulin-like growth factor-1. European Heart Journal 34 782-789. (doi:10.1093/eurheartj/ehr435)

Imrie $\mathrm{H}$, Abbas A, Viswambharan H, Rajwani A, Cubbon RM, Gage M, Kahn M, Ezzat VA, Duncan ER, Grant PJ et al. 2009 Vascular insulinlike growth factor-I resistance and diet-induced obesity. Endocrinology 150 4575-4582. (doi:10.1210/en.2008-1641)

Imrie H, Viswambharan H, Sukumar P, Abbas A, Cubbon RM, Yuldasheva N, Gage M, Smith J, Galloway S, Skromna A et al. 2012 Novel role of the IGF-1 receptor in endothelial function and repair: studies in endothelium-targeted IGF-1 receptor transgenic mice. Diabetes 61 2359-2368. (doi:10.2337/db11-1494)
Iwatsuki K, Tanaka K, Kaneko T, Kazama R, Okamoto S, Nakayama Y, Ito Y, Satake M, Takahashi S, Miyajima A et al. 2005 Runx1 promotes angiogenesis by downregulation of insulin-like growth factor-binding protein-3. Oncogene 24 1129-1137. (doi:10.1038/sj.onc.1208287)

Kielczewski JL, Jarajapu YPR, McFarland EL, Cai J, Afzal A, Calzi SL, Chang KH, Lydic T, Shaw LC, Busik J et al. 2009 Insulin-like growth factor binding protein-3 mediates vascular repair by enhancing nitric oxide generation. Circulation Research 105 897-U174. (doi:10.1161/ CIRCRESAHA.109.199059)

Kim KS, Kim M-S, Seu YB, Chung HY, Kim JH \& Kim J-R 2007a Regulation of replicative senescence by insulin-like growth factor-binding protein 3 in human umbilical vein endothelial cells. Aging Cell 6 535-545. (doi:10.1111/j.1474-9726.2007.00315.x)

Kim KS, Seu YB, Baek SH, Kim MJ, Kim KJ, Kim JH \& Kim JR 2007b Induction of cellular senescence by insulin-like growth factor binding protein-5 through a p53-dependent mechanism. Molecular Biology of the Cell 18 4543-4552. (doi:10.1091/mbc.E07-03-0280)

Kim JH, Park SW, Yu YS, Kim KW \& Kim JH 2012 Hypoxia-induced insulin-like growth factor II contributes to retinal vascularization in ocular development. Biochimie 94 734-740. (doi:10.1016/j.biochi. 2011.11.003)

Kim KS, Kim JE, Choi KJ, Bae S \& Kim DH 2014 Characterization of DNA damage-induced cellular senescence by ionizing radiation in endothelial cells. International Journal of Radiation Biology 90 71-80. (doi:10.3109/09553002.2014.859763)

Kondo T, Vicent D, Suzuma K, Yanagisawa M, King GL, Holzenberger M \& Kahn CR 2003 Knockout of insulin and IGF-1 receptors on vascular endothelial cells protects against retinal neovascularization. Journal of Clinical Investigation 111 1835-1842. (doi:10.1172/JCI200317455)

Lee OH, Bae SK, Bae MH, Lee YM, Moon EJ, Cha HJ, Kwon YG \& Kim KW 2000 Identification of angiogenic properties of insulin-like growth factor II in in vitro angiogenesis models. British Journal of Cancer $\mathbf{8 2}$ 385-391. (doi:10.1054/bjoc.1999.1022)

Leksa V, Godar S, Schiller HB, Fuertbauer E, Muhammad A, Slezakova K, Horejsi V, Steinlein P, Weidle UH, Binder BR et al. 2005 TGF- $\beta$-induced apoptosis in endothelial cells mediated by M6P/IGFII-R and miniplasminogen. Journal of Cell Science 118 4577-4586. (doi:10.1242/ jcs.02587)

Li GL, Barrett EJ, Wang H, Chai WD \& Liu ZQ 2005 Insulin at physiological concentrations selectively activates insulin but not insulin-like growth factor I (IGF-I) or insulin/IGF-I hybrid receptors in endothelial cells. Endocrinology 146 4690-4696. (doi:10.1210/en.2005-0505)

Liu WL, Liu YQ \& Lowe WL 2001 The role of phosphatidylinositol 3-kinase and the mitogen-activated protein kinases in insulin-like growth factor-Imediated effects in vascular endothelial cells. Endocrinology 142 1710-1719. (doi:10.1210/endo.142.5.8136)

Liu B, Lee KW, Anzo M, Zhang B, Zi X, Tao Y, Shiry L, Pollak M, Lin S \& Cohen P 2007 Insulin-like growth factor-binding protein-3 inhibition of prostate cancer growth involves suppression of angiogenesis. Oncogene 26 1811-1819. (doi:10.1038/sj.onc.1209977)

Liu SJ, Zhong Y, You XY, Liu WH, Li AQ \& Liu SM 2014 Insulin-like growth factor 1 opposes the effects of C-reactive protein on endothelial cell activation. Molecular and Cellular Biochemistry 385 199-205. (doi:10.1007/s11010-013-1828-y)

Lofqvist C, Chen J, Connor KM, Smith ACH, Aderman CM, Liu N, Pintar JE, Ludwig T, Hellstrom A \& Smith LEH 2007 IGFBP3 suppresses retinopathy through suppression of oxygen-induced vessel loss and promotion of vascular regrowth. PNAS 104 10589-10594. (doi:10.1073/pnas.0702031104)

Maeng YS, Choi HJ, Kwon JY, Park YW, Choi KS, Min JK, Kim YH, Suh PG, Kang KS, Won MH et al. 2009 Endothelial progenitor cell homing: prominent role of the IGF2-IGF2R-PLC $\beta 2$ axis. Blood 113 233-243. (doi:10.1182/blood-2008-06-162891)

Messmer-Blust A, An X \& Li J 2009 Hypoxia-regulated angiogenic inhibitors. Trends in Cardiovascular Medicine 19 252-256. (doi:10.1016/ j.tcm.2010.02.006) 
Moreno MJ, Ball M, Andrade MF, McDermid A \& Stanimirovic DB 2006 Insulin-like growth factor binding protein-4 (IGFBP-4) is a novel antiangiogenic and anti-tumorigenic mediator secreted by dibutyryl cyclic AMP (dB-cAMP)-differentiated glioblastoma cells. Glia 53 845-857. (doi:10.1002/glia.20345)

Moser DR, Lowe WL Jr, Dake BL, Booth BA, Boes M, Clemmons DR \& Bar RS 1992 Endothelial cells express insulin-like growth factor-binding proteins 2 to 6. Molecular Endocrinology 6 1805-1814. (doi:10.1210/ mend.6.11.1282670)

Muck C, Micutkova L, Zwerschke W \& Jansen-Durr P 2008 Role of insulin-like growth factor binding protein-3 in human umbilical vein endothelial cell senescence. Rejuvenation Research 11 449-453. (doi:10.1089/rej.2007.0628)

Nakao-Hayashi J, Hideki I, Kanayasu T, Morita I \& Murota S 1992 Stimulatory effects of insulin and insulin-like growth factor I on migration and tube formation by vascular endothelial cells. Arteriosclerosis 92 141-149. (doi:10.1016/0021-9150(92)90273-J)

Oh SH, Kim WY, Kim JH, Younes MN, El-Naggar AK, Myers JN, Kies M, Cohen P, Khuri F, Hong WK et al. 2006 Identification of insulin-like growth factor binding protein-3 as a farnesyl transferase inhibitor SCH66336-induced negative regulator of angiogenesis in head and neck squamous cell carcinoma. Clinical Cancer Research 12 653-661. (doi:10.1158/1078-0432.CCR-05-1725)

Otsuka F, Finn AV, Yazdani SK, Nakano M, Kolodgie FD \& Virmani R 2012 The importance of the endothelium in atherothrombosis and coronary stenting. Nature Reviews. Cardiology 9 439-453. (doi:10.1038/nrcardio.2012.64)

Pan Y, Liang H, Liu H, Li D, Chen X, Li L, Zhang CY \& Zen K 2014 Platelet-secreted microRNA-223 promotes endothelial cell apoptosis induced by advanced glycation end products via targeting the insulin-like growth factor 1 receptor. Journal of Immunology 192 437-446. (doi:10.4049/jimmunol.1301790)

Panganiban RA \& Day RM 2013 Inhibition of IGF-1R prevents ionizing radiation-induced primary endothelial cell senescence. PLOS ONE $\mathbf{8}$ e78589. (doi:10.1371/journal.pone.0078589)

Perticone F, Sciacqua A, Perticone M, Laino I, Miceli S, Care I, Galiano Leone G, Andreozzi F, Maio R \& Sesti G 2008 Low-plasma insulin-like growth factor-I levels are associated with impaired endotheliumdependent vasodilatation in a cohort of untreated, hypertensive Caucasian subjects. Journal of Clinical Endocrinology and Metabolism 93 2806-2810. (doi:10.1210/jc.2008-0646)

Png KJ, Halberg N, Yoshida M \& Tavazoie SF 2012 A microRNA regulon that mediates endothelial recruitment and metastasis by cancer cells. Nature 481 190-194. (doi:10.1038/nature10661)

Pollak M 2008 Insulin and insulin-like growth factor signalling in neoplasia. Nature Reviews. Cancer 8 915-928. (doi:10.1038/nrc2536)

Potente M, Gerhardt H \& Carmeliet P 2011 Basic and therapeutic aspects of angiogenesis. Cell 146 873-887. (doi:10.1016/j.cell.2011.08.039)

Rho SB, Dong SM, Kang S, Seo S-S, Yoo CW, Lee DO, Woo JS \& Park S-Y 2008 Insulin-like growth factor-binding protein-5 (IGFBP-5) acts as a tumor suppressor by inhibiting angiogenesis. Carcinogenesis 29 2106-2111. (doi:10.1093/carcin/bgn206)

Rombouts C, Aerts A, Quintens R, Baselet B, El-Saghire H, Harms-Ringdahl M, Haghdoost S, Janssen A, Michaux A, Yentrapalli R et al. 2014 Transcriptomic profiling suggests a role for IGFBP5 in premature senescence of endothelial cells after chronic low dose rate irradiation. International Journal of Radiation Biology 90 560-574. (doi:10.3109/09553002.2014. 905724)

Ruberte J, Ayuso E, Navarro M, Carretero A, Nacher V, Haurigot V, George M, Llombart C, Casellas A, Costa C et al. 2004 Increased ocular levels of IGF-1 in transgenic mice lead to diabetes-like eye disease. Journal of Clinical Investigation 113 1149-1157. (doi:10.1172/JCI19478)

Semenza GL 2012 Hypoxia-inducible factors in physiology and medicine. Cell 148 399-408. (doi:10.1016/j.cell.2012.01.021)

Shelton DN, Chang E, Whittier PS, Choi D \& Funk WD 1999 Microarray analysis of replicative senescence. Current Biology 9 939-945. (doi:10.1016/S0960-9822(99)80420-5)
Slomiany MG \& Rosenzweig SA 2006 Hypoxia-inducible factor-1dependent and -independent regulation of insulin-like growth factor-1stimulated vascular endothelial growth factor secretion. Journal of Pharmacology and Experimental Therapeutics 318 666-675. (doi:10.1124/jpet.106.104158)

Smith LEH, Shen W, Perruzzi C, Soker S, Kinose F, Xu XH, Robinson G, Driver S, Bischoff J, Zhang B et al. 1999 Regulation of vascular endothelial growth factor-dependent retinal neovascularization by insulin-like growth factor-1 receptor. Nature Medicine 5 1390-1395. (doi:10.1038/70963)

Spoerri PE, Ellis EA, Tarnuzzer RW \& Grant MB 1998 Insulin-like growth factor - receptor and binding proteins in human retinal endothelial cell cultures of diabetic and non diabetic origin. Growth Hormone \& IGF Research 8 125-132. (doi:10.1016/S1096-6374(98)80102-0)

Stearns M, Tran J, Francis MK, Zhang H \& Sell C 2005 Activated ras enhances insulin-like growth factor I induction of vascular endothelial growth factor in prostate epithelial cells. Cancer Research 65 2085-2088. (doi:10.1158/0008-5472.CAN-04-4100)

Sukhanov S, Higashi Y, Shai SY, Vaughn C, Mohler J, Li Y, Song YH, Titterington J \& Delafontaine P 2007 IGF-1 reduces inflammatory responses, suppresses oxidative stress, and decreases atherosclerosis progression in ApoE-deficient mice. Arteriosclerosis, Thrombosis, and Vascular Biology 27 2684-2690. (doi:10.1161/ATVBAHA.107.156257)

Sumpio BE, Riley JT \& Dardik A 2002 Cells in focus: endothelial cell. International Journal of Biochemistry \& Cell Biology 34 1508-1512. (doi:10.1016/S1357-2725(02)00075-4)

Thum T, Hoeber S, Froese S, Klink I, Stichtenoth DO, Galuppo P, Jakob M, Tsikas D, Anker SD, Poole-Wilson PA et al. 2007a Age-dependent impairment of endothelial progenitor cells is corrected by growthhormone-mediated increase of insulin-like growth-factor-1. Circulation Research 100 434-443. (doi:10.1161/01.RES.0000257912.78915.af)

Thum T, Fleissner F, Klink I, Tsikas D, Jakob M, Bauersachs J \& Stichtenoth DO $2007 b$ Growth hormone treatment improves markers of systemic nitric oxide bioavailability via insulin-like growth factor-I. Journal of Clinical Endocrinology and Metabolism 92 4172-4179. (doi:10.1210/ jc.2007-0922)

Tivesten A, Bollano E, Andersson I, Fitzgerald S, Caidahl K, Sjogren K, Skott O, Liu JL, Mobini R, Isaksson OGP et al. 2002 Liver-derived insulin-like growth factor-I is involved in the regulation of blood pressure in mice. Endocrinology 143 4235-4242. (doi:10.1210/en.2002-220524)

Tucci M, Nygard K, Tanswell BV, Farber HW, Hill DJ \& Han VKM 1998 Modulation of insulin-like growth factor (IGF) and IGF binding protein biosynthesis by hypoxia in cultured vascular endothelial cells. Journal of Endocrinology 157 13-24. (doi:10.1677/joe.0.1570013)

Valastyan S \& Weinberg RA 2011 Tumor metastasis: molecular insights and evolving paradigms. Cell 147 275-292. (doi:10.1016/j.cell. 2011.09.024)

Volpert O, Jackson D, Bouck N \& Linzer DIH 1996 The insulin-like growth factor II/mannose 6-phosphate receptor is required for proliferininduced angiogenesis. Endocrinology 137 3871-3876. (doi:10.1210/ endo.137.9.8756559)

Wang W, Kumar P, Wang WZ, Epstein J, Helman L, Moore JV \& Kumar S 1998 Insulin-like growth factor II and PAX3-FKHR cooperate in the oncogenesis of rhabdomyosarcoma. Cancer Research $\mathbf{5 8} 4426-4433$.

Wang H, Liu Z, Li G \& Barrett EJ 2006 The vascular endothelial cell mediates insulin transport into skeletal muscle. American Journal of Physiology. Endocrinology and Metabolism 291 E323-E332. (doi:10.1152/ ajpendo.00047.2006)

Wang X, Huang W, Liu G, Cai W, Millard RW, Wang Y, Chang J, Peng T \& Fan GC 2014 Cardiomyocytes mediate anti-angiogenesis in type 2 diabetic rats through the exosomal transfer of miR-320 into endothelial cells. Journal of Molecular and Cellular Cardiology 74 139-150. (doi:10.1016/j.yjmcc.2014.05.001)

Warren RS, Yuan H, Matli MR, Ferrara N \& Donner DB 1996 Induction of vascular endothelial growth factor by insulin-like growth factor 1 in

Published by Bioscientifica Ltd. 
colorectal carcinoma. Journal of Biological Chemistry 271 29483-29488. (doi:10.1074/jbc.271.46.29483)

Wheatcroft SB \& Kearney MT 2009 IGF-dependent and IGF-independent actions of IGF-binding protein-1 and -2: implications for metabolic homeostasis. Trends in Endocrinology and Metabolism 20 153-162. (doi:10.1016/j.tem.2009.01.002)

Wilkinson-Berka JL, Wraight C \& Werther G 2006 The role of growth hormone, insulin-like growth factor and somatostatin in diabetic retinopathy. Current Medicinal Chemistry 13 3307-3317. (doi:10.2174/ 092986706778773086)

Wood AW, Schlueter PJ \& Duan C 2005 Targeted knockdown of insulin-like growth factor binding protein-2 disrupts cardiovascular development in zebrafish embryos. Molecular Endocrinology 19 1024-1034. (doi:10.1210/me.2004-0392)

Yang YW-H, Piolo P, Fiorelli G, Brandi ML \& Rechler MM 1993 Cyclic adenosine monophosphate stimulates insulin-like growth factor binding protein- 4 and its messenger ribonucleic acid in a clonal endothelial cell line. Endocrinology 133 343-351. (doi:10.1210/endo. 133.1.7686482)

Yang AL, Yeh CK, Su CT, Lo CW, Lin KL \& Lee SD 2010 Aerobic exercise acutely improves insulin- and insulin-like growth factor-1-mediated vasorelaxation in hypertensive rats. Experimental Physiology 95 622-629. (doi:10.1113/expphysiol.2009.050146)

Yuldasheva NY, Rashid ST, Haywood NJ, Cordell P, Mughal R, Viswambharan H, Imrie H, Sukumar P, Cubbon RM, Aziz A et al. 2014 Haploinsufficiency of the insulin-like growth factor-1 receptor enhances endothelial repair and favorably modifies angiogenic progenitor cell phenotype. Arteriosclerosis, Thrombosis, and Vascular Biology $\mathbf{3 4}$ 2051-2058. (doi:10.1161/atvbaha.114.304121)

Zeng G \& Quon MJ 1996 Insulin-stimulated production of nitric oxide is inhibited by wortmannin. Direct measurement in vascular endothelial cells. Journal of Clinical Investigation 98 894-898. (doi:10.1172/ JCI118871)

Zhang C, Lu L, Li Y, Wang X, Zhou J, Liu Y, Fu P, Gallicchio MA, Bach LA \& Duan C 2012 IGF binding protein-6 expression in vascular endothelial cells is induced by hypoxia and plays a negative role in tumor angiogenesis. International Journal of Cancer 130 2003-2012. (doi:10.1002/ijc.26201)

Zhang Q, Soderland C \& Steinle JJ 2013a Regulation of retinal endothelial cell apoptosis through activation of the IGFBP-3 receptor. Apoptosis $\mathbf{1 8}$ 361-368. (doi:10.1007/s10495-012-0793-3)

Zhang Q, Jiang Y, Toutounchian JJ, Soderland C, Yates CR \& Steinle JJ $2013 b$ Insulin-like growth factor binding protein-3 inhibits monocyte adhesion to retinal endothelial cells in high glucose conditions. Molecular Vision 19 796-803.

Zhang Q, Jiang Y, Miller MJ, Peng B, Liu L, Soderland C, Tang J, Kern TS, Pintar J \& Steinle JJ 2013c IGFBP-3 and TNF- $\alpha$ regulate retinal endothelial cell apoptosis. Investigative Ophthalmology \& Visual Science 54 5376-5384. (doi:10.1167/iovs.13-12497)

Zhang Q, Soderland D \& Steinle JJ 2014 TNF $\alpha$ Inhibits iGFBP-3 through activation of p38a and casein kinase 2 in human retinal endothelial cells. PLoS ONE 9 e103578. (doi:10.1371/journal.pone.0103578)

Received in final form 20 October 2014

Accepted 28 October 2014

Accepted Preprint published online 28 October 2014
(C) 2015 Society for Endocrinology Printed in Great Britain
Published by Bioscientifica Ltd. 